\title{
Diversity and species composition of fruit flies (Diptera: Tephritidae) in Lombok Island, Indonesia
}

\author{
SYARRON HUDIWAKU ${ }^{1,2, \boldsymbol{v}}$, TOTO HIMAWAN ${ }^{1}$, AKHMAD RIZALI $^{\mathbf{1}}$ \\ ${ }^{1}$ Department of Plant Pest and Diseases, Faculty of Agriculture, Universitas Brawijaya. Jl. Veteran, Malang 65145, East Java, Indonesia. \\ Tel./fax.: +62-341-560011, `email: hudiwakusyarron@ gmail.com. \\ ${ }^{2}$ Agriculture Quarantine Agency Class 1 Mataram. Jl. Raya Pelabuhan Lembar No. 9, West Lombok 83364, West Nusa Tenggara, Indonesia
}

Manuscript received: 12 July 2021. Revision accepted: 28 September 2021.

\begin{abstract}
Hudiwaku S, Himawan T, Rizali A. 2021. Diversity and species composition of fruit flies (Diptera: Tephritidae) in Lombok Island, Indonesia. Biodiversitas 22: 4608-4616. Fruit flies (Diptera: Tephritidae) are pests of several horticultural crops that can reduce the quality and quantity of fruit production. Information on fruit flies in Lombok Island, Indonesia, is still limited. However, it is predicted to have a high diversity of fruit flies because this island belongs to the Wallacea region. The aims of this research was to study the diversity and species composition of fruit flies in different habitat types in Lombok Island. The research was carried out on two habitat types, i.e., tropical rainforest and orchard with each habitat type consisted of three different sites that located spread across Lombok Island as replication. The research was carried out on two habitat types, i.e., tropical rainforest and orchard, with each habitat type consisted of three different sites spread across Lombok Island as replication. A sampling of fruit flies was conducted using parapheromone traps from March to June 2020. Twenty-two species and 210,267 individual fruit flies were collected from all locations during the study period. The most dominant species were Bactrocera carambolae, Bactrocera limbifera, Zeugodacus caudatus, and Bactrocera dorsalis. Based on the ANOVA, habitat types significantly affected the abundance but not the species richness of fruit flies. The visualization results obtained from the NMDS ordination indicated a difference in the species composition of fruit flies between the two habitats. In conclusion, habitat types are an essential factor in shaping the community of fruit flies in Lombok Island.
\end{abstract}

Keywords: Bactrocera, orchard, parapheromone trap, tropical rainforest, Wallacea region

\section{INTRODUCTION}

Lombok Island, Indonesia, is a habitat for tropical biodiversity. It is categorized as a small island with an area of $4738.7 \mathrm{~km}^{2}$ (Sapta et al. 2015). The biogeography of Lombok Island belongs to the Wallacea region located between the Sunda and Sahul Shelves, with the Wallace and Lydekker lines as boundaries. Wallacea is the archipelago zone to act as a two-way filter between the Asian and Australian-Papuan biogeographical realms. Each deep-water barrier between islands effectively limits some species' eastward or westward movement (Reilly et al. 2018). Thus, flora and fauna in this region are a transition between Southeast Asia and Australia. Sapta et al. (2015) suggested that Lombok Island is a border region between flora and fauna of Asia and Australia and form unique ecosystem diversity. As a tropical Island in the Wallacea region, Lombok has a wide variety of endemic flora and fauna with several types of habitats in tropical rainforests and orchards. According to Doorenweerd et al. (2020), in any case, the geographic history of the islands has undoubtedly played a significant role in the evolution of the fauna.

Fruit flies (Diptera: Tephritidae) are a group of insect pests suspected to have high diversity in Lombok Island. However, these also have the potential to reduce the quality and quantity of fruit production. Doorenweerd et al. (2020) suggested that the Dacini fruit flies (Tephritidae: Dacinae) are a tribe of 938 described exclusively Old World species.
Fruit flies attack caused economic impacts that include direct yield losses, increased production costs due to suppression actions, and a limiting factor in international trade in fresh agricultural commodities (Grove et al. 2019). Fruit fly species of the tribe Dacini are key pest groups in Asia and the Pacific regions (Dominiak and Worlsey 2018). They pose a serious threat to horticulture because of the damage inflicted and quarantine implications (Linda et al. 2018). Fruit flies inhabit a variety of habitats, from tropical rainforests to orchards. There are found in almost all habitats with appropriate plant life worldwide, ranging from rainforest to open savannah, with approximately 1,400 species of fruit flies develop in fleshy fruits (Zubair et al. 2019). However, the diversity and composition of species can also differ in each habitat. Differences in land use, habitat area, percentage of canopy cover, and varied vegetation diversity can affect the diversity of fruit flies in that area. Differences in the composition of these insects are influenced not only by the number of flowering plants but also by environmental factors such as temperature, humidity, and canopy cover (Foster et al. 2011).

There is an association between habitat type and fruit fly diversity. Land-use types affect the diversity of insects; thus, the habitat condition such as understory flowering plants in each land-use type appears to influence the species composition of insects (Jihadi et al. 2021). Tropical rainforest areas are natural ecosystems that have high species diversity. Tan and Nishida (2013) suggested that in the endemic rainforest of the Southeast Asia region, males 
of certain dacine fruit flies of the Bactrocera and Zeugodacus genera (Diptera: Tephritidae) forage and feed on the nectarless orchid flowers, such as Bulbophyllum spp. and Dendrobium spp. Meanwhile, Grimbacher et al. (2014) suggested that the several studies of Tephritidae from multiple tropical regions have also documented relatively high levels of specificity to particular plant species; thus, the Tephritidae may be more specialized than other insect groups associated with fruits of rainforest plants. Fahrig et al. (2011) stated that the forest area has a higher flora, thus creating a conducive environment for fruit flies even in limited numbers.

The orchard in Lombok Island has the potential for superior fruit production. The production potential of 17 fruit commodities in Lombok Island in 2018 was 273,102,800 kilograms (Suntono et al. 2019). Cashew (Anacardium occidentale) production in 2015 was 4,233,000 kilograms (Badan Pusat Statistik NTB 2020). Mango (Mangifera indica) reached production of 74,040,600 kilograms in 2018, whereas Mangosteen (Garcinia mangostana) was 11,082,400 kilograms (Suntono et al. 2019). This may impact the diversity of fruit flies with pest status due to the availability of hosts. Host plants cultivated extensively and available throughout the year; this condition affected the population and distribution of fruit fly species in such areas (Linda et al. 2018).

Lombok Island also has a tropical rainforest area with a balanced ecosystem, so it has the potential to have a high diversity of pest and non-pest fruit flies. Differences in habitat types are thought to be a determining factor for the diversity of fruit flies because they provide a suitable place for fruit fly life. Fruit flies use plant parts as resources for food, reproduction, and shelter. Each species has a specific host and shelter suitability associated with its habitat. Host specificity is likely to vary depending on the resource that particular species are utilizing (Grimbacher et al. 2014). The microclimate and the host plant architecture significantly influence the abundance and behavior of phytophagous insects (Mokam et al. 2014).

An orchard that certain fruit plants dominate is a limiting factor for the diversity of fruit flies. The presence of the host plays an essential role in the dominance of fruit fly species that are classified as pests. This condition is different from rainforest areas with a high diversity of vegetation, so the dominance of a fruit fly species will be limited. The absence of dominance causes the competition between fruit fly species to be balanced so that the diversity is higher. There is a relationship between host plants in the habitat and the diversity of fruit flies. In the subfamily Dacinae, the relationship between host plants and flies is thought to be particularly strong since the host plant is considered central for larval and adult feeding, mating, and oviposition (Mokam et al. 2014).

The extent to which habitat differences affect the diversity and composition of fruit fly species in Lombok Island, Indonesia has not been widely studied. Furthermore, the availability of information on the diversity and composition of fruit fly species in specific habitats such as rainforests and orchards in Lombok Island is also still limited. Thus, this research aims to study the diversity and species composition of fruit flies in different habitat types in Lombok Island.

\section{MATERIALS AND METHODS}

\section{Study area and plot determination}

The study was conducted in two habitat types based on the land-uses, i.e., tropical rainforest and orchard. Each habitat type consisted of three different sites spread across Lombok Island as a replication for a total of six observation sites (Figure 1).

The predominant vegetation species in the tropical rainforest is wild plants, i.e., Indian rosewood (Dalbergia latifolia), bongang (Tabernaemontana macrocarpa), new guinea walnut (Dracontomelon dao), and rain tree (Samanea saman). Meanwhile, cultivated plants in orchard habitats, such as cashews (Anacardium occidentale), mangosteen (Garcinia mangostana), and mango (Mangifera indica), are dominant. All of the observation sites had rain, while the orchard habitats had a fruiting season. The average temperature and humidity during the study (March to June 2020) in the tropical rainforest habitat were $25.8 \mathrm{oC}$ and $89.9 \%$, while those in the orchard habitat were 25.9 oC and $80.3 \%$, based on data recorded on the TempU 03 temperature and humidity multiuse USB data logger installed in sites.

Table 1. The observation sites of tropical rainforest and orchard habitats used in Lombok Island

\begin{tabular}{|c|c|c|c|c|c|}
\hline Lands used & Observation sites & Coordinates & $\begin{array}{c}\text { Altitude } \\
\text { (m asl.) }\end{array}$ & Administration location & $\begin{array}{l}\text { Dominant } \\
\text { vegetation }\end{array}$ \\
\hline \multirow[t]{3}{*}{ Tropical rainforest } & Kerandangan nature park & $\mathrm{S} 8^{\circ} 28.757^{\prime} ; \mathrm{E} 116^{\circ} 03.122^{\prime}$ & $44-104$ & Batulayar, West Lombok & Wild plants \\
\hline & Suranadi nature park & S8 $34.093^{\prime} ;$ E116 ${ }^{\circ} 13.905^{\prime}$ & $207-238$ & Narmada, West Lombok & Wild plants \\
\hline & Lemor forest & $\mathrm{S}^{\circ} 30.794^{\prime} ; \mathrm{E} 116^{\circ} 34.085^{\prime}$ & $427-493$ & Suela, East Lombok & Wild plants \\
\hline \multirow[t]{3}{*}{ Orchard } & Gangga orchard & $\mathrm{S} 8^{\circ} 19.960^{\prime} ; \mathrm{E} 116^{\circ} 12.961^{\prime}$ & $97-197$ & Gangga, North Lombok & $\begin{array}{l}\text { Cultivated plant } \\
\text { (Cashews) }\end{array}$ \\
\hline & Lingsar orchard & $\mathrm{S} 8^{\circ} 32.814^{\prime} ; \mathrm{E} 116^{\circ} 11.828^{\prime}$ & $201-292$ & Lingsar, West Lombok & $\begin{array}{l}\text { Cultivated plant } \\
\text { (Mangosteen) }\end{array}$ \\
\hline & Lemor orchard & $\mathrm{S}^{\circ} 30.805^{\prime} ; \mathrm{E} 116^{\circ} 33.636^{\prime}$ & $470-533$ & Suela, East Lombok & $\begin{array}{l}\text { Cultivated plant } \\
\text { (Mango) }\end{array}$ \\
\hline
\end{tabular}

Note: * asl: above sea level 

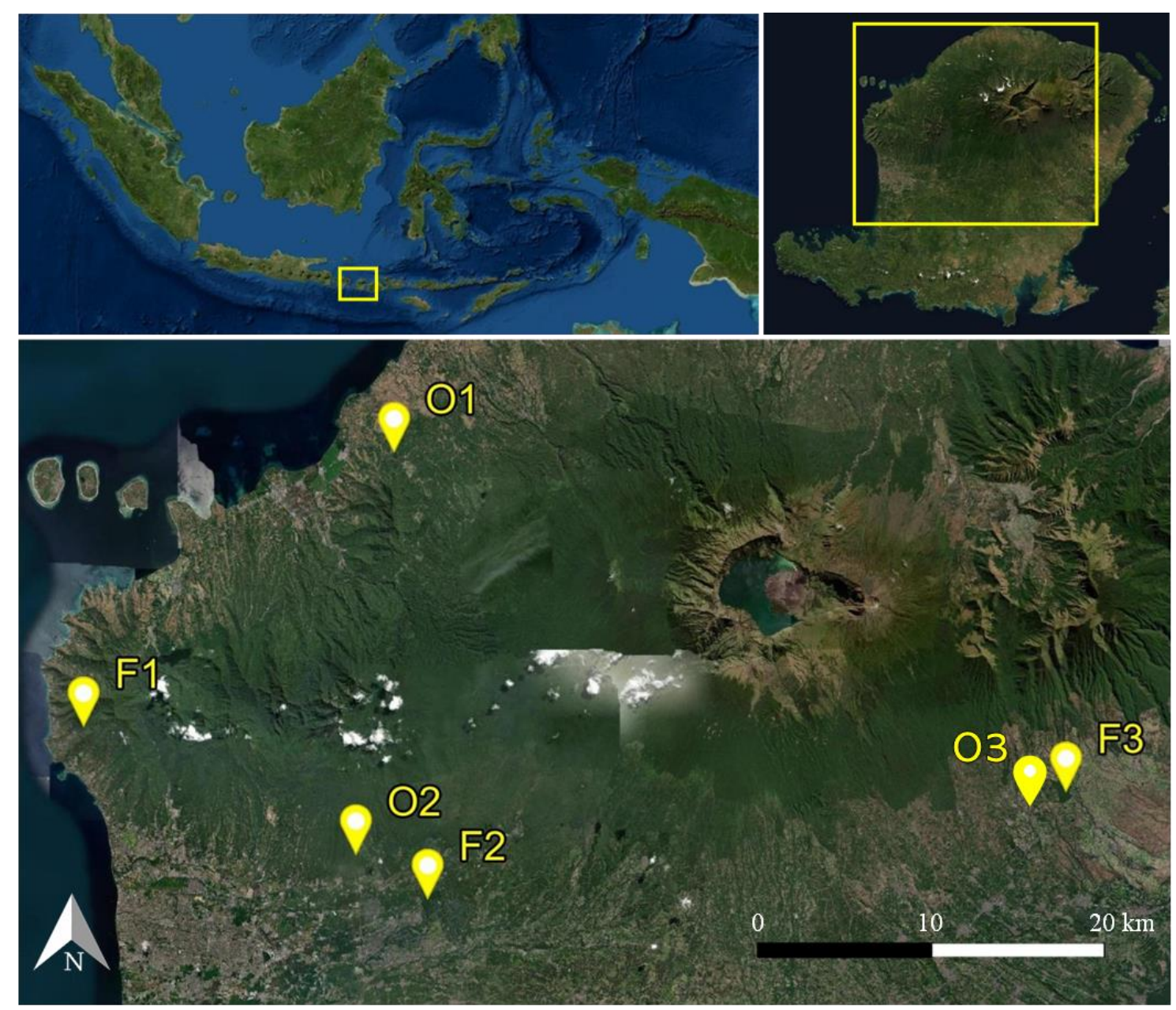

Figure 1. Map of the observation sites in Lombok Island. F1: Tropical rainforest (Kerandangan nature park); F2: Tropical rainforest (Suranadi nature park); F3: Tropical rain forest (Lemor forest); O1: Orchard (Gangga orchard); O2: Orchard (Lingsar orchard); O3: Orchard (Lemor orchard).

The tropical rainforest habitats selected were Kerandangan nature park, Suranadi nature park, and Lemor forest, whereas the orchard habitats were Gangga, Lingsar, and Lemor orchard (Table 1). Six observation plots were determined at each habitat site using the one-kilometer transect method, with a $200 \mathrm{~m}$ between plots. Two traps, each containing a different parapheromone, i.e., Methyl eugenol (ME) or Cue lure (CL), were used per plot. In total, 12 traps were used per transect or 72 traps overall across all sites.

\section{Trapping and identification of fruit flies}

In each plot, fruit fly samples were obtained by trapping using two dry-type Steiner traps. Each trap was added with a different parapheromone attractant, i.e., Methyl eugenol or Cue lure, with a $25 \mathrm{~m}$ between them. Royer and Mayer (2018) suggested that the male fruit fly attractants, Cue lure, and Methyl eugenol, are essential in monitoring and controlling pest fruit fly species. Moreover, these attractants are necessary for managing pest species through male annihilation techniques and trapping to detect invasive pest populations (Royer et al. 2019). The trap is hung on a tree branch at the height of 1.5-2 m above ground level. Trapping at each location was carried out 15 times at weekly intervals. The attractant was added each time the sample was taken. Trapped fruit flies were collected in plastic containers for identification purposes. Trapping was carried out from March to June 2020.

Identification of fruit flies was carried out morphologically using a Nikon SMZ 745T trinocular stereo microscope with a Nikon DS-Fi3 camera. Each morphological character of fruit flies was documented using imaging software NIS-Elements version 5.20.00. Identification refers to the identification key book for tropical fruit flies in Southeast Asia, Indomalaya to Northwest Australia (Drew and Romig 2013).

\section{Data analysis}

Fruit fly species richness was measured in terms of the mean number of species found, while fruit fly individual abundance was measured in the mean number of individuals. Thus, all data has a normal distribution based on the Shapiro-Wilk test. To determine differences in fruit fly diversity in tropical rainforest and orchard habitats, species richness and individual abundance were analyzed using analysis of variance (One-way ANOVA; $\mathrm{P}<0.05$ ). If 
there is a difference, it was further tested using the Tukey significant difference test (HSD) at a 5\% level using the SigmaPlot 14.5 software. Meanwhile, to determine the difference between the species composition of fruit flies in tropical rainforest and orchard habitats, non-metric multidimensional scaling (NMDS) ordination was used to visualize differences in species composition based on the Bray-Curtis index $(B C i j)$. The analysis was carried out using Paleontological Statistics software version 4.03.

\section{RESULTS AND DISCUSSION}

\section{Diversity of fruit flies in Lombok Island}

The results indicated that a total of fruit fly species were collected from both habitats, with a higher number of fruit fly species found in the tropical rainforest habitat (22 species) than in the orchard habitat (19 species). Some species found in tropical rainforest habitats were not found in orchard habitats (Table 2). All 19 species from the orchards were also found in the tropical rainforest habitats. In comparison, three species were only found in tropical rainforest habitats, namely Dacus dorjii, Bactrocera apicopicta, and Bactrocera pruniae. Also, there were nine unique fruit fly species endemic to Lombok Island, namely Bactrocera apicopicta, Bactrocera bimaculata, Bactrocera pseudocucurbitae, Zeugodacus borongensis, Zeugodacus sasaotiae, Bactrocera pruniae, Dacus conopsoides, Dacus discophorus, and Dacus dorjii. All except B. pruniae were allocated non-pest status.

The overall abundance of fruit flies found in both habitats was 210,267 individuals. However, the individual abundance of fruit flies in the tropical rainforest habitat (74,783 individuals) was lower than that of fruit flies in the orchard habitat (135,484 individuals). The highest individual abundance in both habitats was $B$. carambolae (98,191 individuals), whereas the lowest was $D$. dorjii (1 individual) and $B$. pruniae (1 individual) (Table 2). Total individual numbers of four species in both habitats that have dominant compared to other species, namely $B$. carambolae $(98,191$ individuals), B. limbifera $(60,743$ individuals), $Z$. caudatus (19,236 individuals), and B. dorsalis (14,200 individuals), while the rest were nondominant.

Not all of the fruit flies found in both habitats were pests and economically significant. Only seven species are known to have pest status and economically important, namely $B$. carambolae, $B$. dorsalis, $Z$. cucurbitae, $B$. umbrosa, B. albistrigata, $B$. musae, and $B$. pruniae that infest commercial fruits such as mango, melon, and jackfruit. The other species collected were non-pest and non-economically important because their infestation in commercial crops was unknown. Seven species of fruit flies were collected using the parapheromone attractant ME. In contrast, the other 15 species used the parapheromone attractant CL.

Table 2. Species richness and abundance of fruit flies in tropical rainforest and orchard habitats on Lombok Island

\begin{tabular}{|c|c|c|c|c|c|c|c|}
\hline \multirow[b]{2}{*}{ Species } & \multicolumn{3}{|c|}{ Individual abundance } & \multirow[b]{2}{*}{ Dominance } & \multirow[b]{2}{*}{ Attractant } & \multirow[b]{2}{*}{ Characteristics } & \multirow[b]{2}{*}{ Status } \\
\hline & $\begin{array}{c}\text { Tropical } \\
\text { rainforest }\end{array}$ & Orchard & Total & & & & \\
\hline B. carambolae & 32,584 & 65,607 & 98,191 & $\mathrm{~d}$ & Methyl eugenol & Polyphagous & Pest \\
\hline B. limbifera & 24,913 & 35,830 & 60,743 & $\mathrm{~d}$ & Cue lure & Oligophagous & Non-pest \\
\hline Z. caudatus & 3,769 & 15,467 & 19,236 & $\mathrm{~d}$ & Cue lure & Oligophagous & Non-pest \\
\hline B. dorsalis & 3,339 & 10,861 & 14,200 & $\mathrm{~d}$ & Methyl eugenol & Polyphagous & Pest \\
\hline Z. cucurbitae & 2,902 & 2,236 & 5,138 & nd & Cue lure & Polyphagous & Pest \\
\hline B. bimaculata & 2,763 & 1,783 & 4,546 & nd & Cue lure & Unknown & Non-pest \\
\hline B. nigrotibialis & 1,502 & 1,321 & 2,823 & nd & Cue lure & Oligophagous & Non-pest \\
\hline Z. sasaotiae & 1,910 & 362 & 2,272 & nd & Cue lure & Unknown & Non-pest \\
\hline B. umbrosa & 236 & 851 & 1,087 & nd & Methyl eugenol & Oligophagous & Pest \\
\hline B. albistrigata & 134 & 590 & 724 & nd & Cue lure & Polyphagous & Pest \\
\hline B. pseudocucurbitae & 205 & 211 & 416 & nd & Cue lure & Unknown & Non-pest \\
\hline B. moluccensis & 116 & 234 & 350 & nd & Cue lure & Monophagous & Non-pest \\
\hline D. conopsoides & 67 & 88 & 155 & nd & Cue lure & Unknown & Non-pest \\
\hline Z. exornata & 135 & 16 & 151 & nd & Cue lure & Unknown & Non-pest \\
\hline B. neocognata & 104 & 6 & 110 & nd & Methyl eugenol & Monophagous & Non-pest \\
\hline B. verbascifoliae & 84 & 12 & 96 & nd & Methyl eugenol & Monophagous & Non-pest \\
\hline B. musae & 7 & 4 & 11 & nd & Methyl eugenol & Polyphagous & Pest \\
\hline Z. borongensis & 4 & 4 & 8 & nd & Cue lure & Unknown & Non-pest \\
\hline B. apicopicta & 5 & 0 & 5 & nd & Cue lure & Unknown & Non-pest \\
\hline D. discophorus & 2 & 1 & 3 & nd & Cue lure & Monophagous & Non-pest \\
\hline D. dorjii & 1 & 0 & 1 & nd & Cue lure & Unknown & Non-pest \\
\hline B. pruniae & 1 & 0 & 1 & nd & Methyl eugenol & Oligophagous & Pest \\
\hline No. individual & 74,783 & 135,484 & 210,267 & & & & \\
\hline No. species & 22 & 19 & 22 & & & & \\
\hline
\end{tabular}

Note: $*$ d: dominant species, nd: non-dominant species 


\section{Effect of habitat types on diversity and species composition of fruit flies}

Based on the One-way ANOVA, species richness was not significantly different between habitat types $(\mathrm{P}=$ 0.847). Meanwhile, the individual abundance between habitat types was significantly different based on the Oneway ANOVA $(P=0.007)$ in Lombok Island. The mean of species richness in the tropical rainforest habitat $(16.00 \pm$ $5.20)$ is almost the same as in the orchard habitat (15.33 \pm 2.08). By contrast, the mean number of individuals in the tropical rainforest habitat $(24,927.67 \pm 5,656.96)$ was significantly lower than that in the orchard habitat $(45,161.33 \pm 3,750.24)$ (Table 3).
The species composition is based on the individual abundance in each habitat type. The pie chart shows the species composition of fruit flies in the tropical rainforest (Figure 2a) and orchard (Figure 2b) habitats. The results of NMDS ordination visualize the different groupings of species composition between the tropical rainforest and orchard habitats, with species in the three locations of tropical rainforest habitats separated from the three locations in orchard habitats (Figure 3). The visualization results obtained from the NMDS ordination indicated a difference in the species composition of fruit flies between the two habitats.

Table 3. Different of species richness and abundance of fruit flies between tropical rainforest and orchard habitats.

\begin{tabular}{lccc}
\hline \multicolumn{1}{c}{ Variable } & \multicolumn{2}{c}{ Habitat type $(\overline{\mathrm{X}} \pm$ SD) } & \multirow{2}{*}{ P-value } \\
\cline { 2 - 3 } & Tropical rainforest & Orchard & 0.847 \\
Species richness $(\mathrm{S})$ & $16.00 \pm 5.20 \mathrm{a}$ & $15.33 \pm 2.08 \mathrm{a}$ & 0.007 \\
Individual abundance $(\mathrm{N})$ & $24,927.67 \pm 5,656.96 \mathrm{a}$ & $45,161.33 \pm 3,750.24 \mathrm{~b}$ & \\
\hline Nonn & &
\end{tabular}

Note: $\overline{\mathrm{x}}=$ mean and SD = standard deviation of species richness and individual abundance. Means followed by the same letters within each row are not significantly different at $P<0.05$ according to Tukey's test
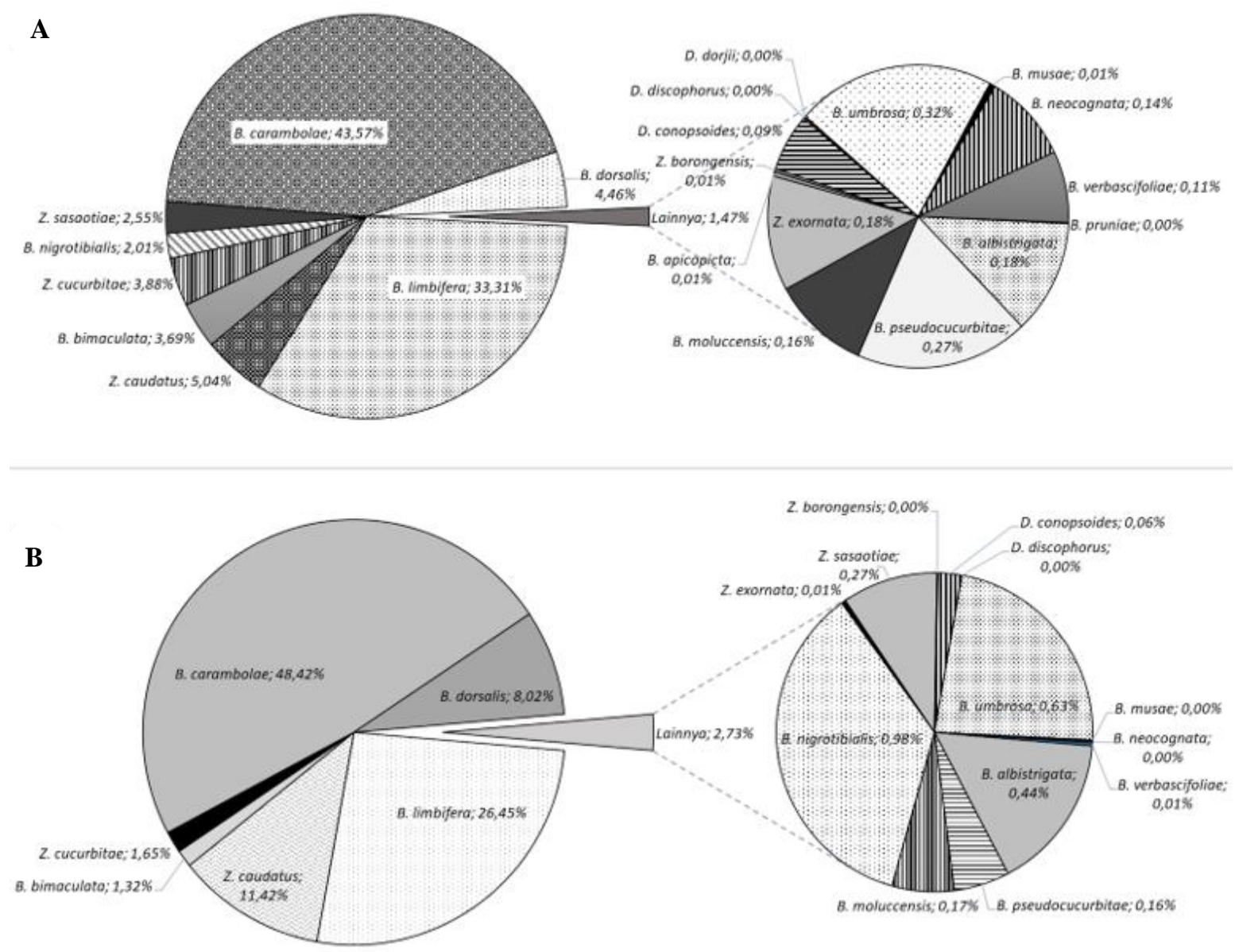

Figure 2. Pie diagram of the species composition of fruit flies in the habitats. A. Tropical rainforest habitat, B. Orchard habitat 


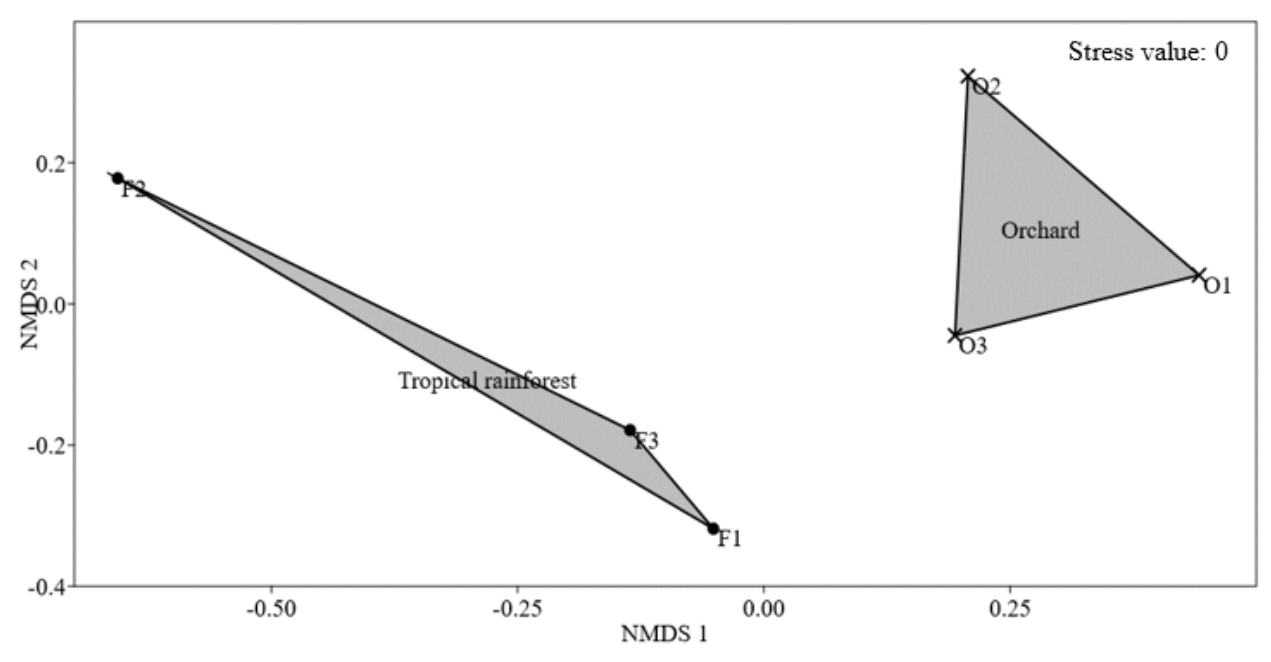

Figure 3. NMDS ordination of species composition of fruit flies between tropical rainforest and orchard habitats based on the Bray-Curtis dissimilarity index. Letter followed by number indicates site code. F1: Kerandangan nature park; F2: Suranadi nature park; F3: Lemor forest; O1: Gangga orchard; O2: Lingsar orchard; and O3: Lemor orchard

\section{Discussion}

Several factors can affect species richness and the individual abundance of fruit flies in a habitat. Fruit flies in carrying out their lives depend on various factors. According to Raghuvanshi et al. (2012), the fruit fly activity varies greatly depending mainly on the prevailing climatic conditions and the diversity of other hosts in a particular agro-ecosystem. There is a notable seasonality in trap catches, with a drastic increase in fruit fly abundance and diversity over summer, which coincides with the wet season and fruiting period for many host trees (Royer and Hancock 2012). In general, the effect of differences in hosts in the habitat is important in determining the number of fruit fly species present. Based on the land use system, tropical rainforest habitats with heterogeneous vegetation have higher host types than orchard habitats with homogeneous vegetation. The numbers of fruit fly species collected in the forest were higher than in the orchard and home estate because vegetation diversity in the forest varies more (Linda et al. 2018). In the tropics, the wide variety of plant resources available to insects combined with the high diversity of plants means that specialization on particular plant parts and even plant species are common (Grimbacher et al. 2014).

The different species of fruit flies found in the habitat can also be influenced by the preference of each species for a particular habitat. Linda et al. (2018) suggested that several species, such as $B$. umbrosa, $B$. dorsalis, and $B$. frauenfeldi were found in all land use types. Still, $B$. retrorsa, $B$. strigifinis, and $B$. furvilineata were only found in forest areas. The higher species richness of fruit flies in tropical rainforest habitats is also due to the presence of rare species, i.e., $D$. dorjii, B. apicopicta, and B. pruniae found only in this habitat. The fruit fly species are classified as rare, i.e., B. apicopicta, B. pruniae, and D. dorjii, which have not been previously reported in Lombok Island. This is why the number of fruit fly species found in tropical rainforest habitats is higher than in orchard habitats. Heterogeneous habitat like a forest is an area with high and stable vegetation diversity; the number of fruit fly species in this kind of area is also high, although some of them are not the dominant species (Linda et al. 2018). Drew and Romig (2013) suggested that B. apicopicta was attracted to CL attractants in dry primary sclerophyll forest habitat. Tropical rainforest habitats with more balanced ecosystems are considered capable of protecting several species of these fruit flies. Tropical rainforest habitat is deemed capable of providing a place for a more diverse species of fruit fly, but its population is more limited. Meanwhile, orchard habitats are considered more ideal for developing high populations, which are generally pests. The availability of hosts such as fruits will result in the number of individual species with pest statuses, such as $B$. carambolae and B. dorsalis, becoming dominant. Supratiwi et al. (2020) suggest that the most prevalent fruit flies found at the study site were $B$. dorsalis (Hendel) and $B$. carambolae (Drew \& Hancock). According to Vargas et al. (2015), B. dorsalis and B. carambolae are known as sympatric sibling species, native to South-these exotic or ornamental fruiting trees showed East Asia and are frequently found in the same area. Each ecosystem has a continuous availability of hosts to support the life sustainability of fruit fly species.

The abundance of individuals in both habitats was not evenly distributed across all species, indicating the dominance of certain species such as $B$. carambolae, $B$. limbifera, Z. caudatus, and B. dorsalis. This could be why the species richness of fruit flies in tropical rainforest and orchard habitats is not significantly different while their abundance is very different. The dominance of these species is due to the presence of $B$. carambolae and $B$. dorsalis, which are the primary pests on fruit trees with a wide host range. Commonly, $B$. dorsalis and $B$. carambolae are known as highly polyphagous fruit flies 
(CABI 2019). According to Aryuwandari et al. (2020), B. dorsalis and $B$. carambolae infested the widest range of fruits; thus, the high frequency of overlapping hosts is evidence of the overlapping of host utilization fruit flies is common particularly for B. dorsalis and B. carambolae. Meanwhile, $B$. limbifera and $Z$. caudatus were not classified as pests and were oligophages, but their populations were dominant in the fruit fly community structure in both habitat types. The reason is that $B$. limbifera is often found in tropical rainforest habitat where their wild host plants, such as Dracontomelon dao and Aglaia sp., are found (Drew and Romig 2013). By contrast, Z. caudatus is known not to infest fruit plants but has a host on male flowers of butternut squash (Cucurbita moschata) (Drew and Romig 2013).

The host range and presence of suitable host plants in the habitat may contribute to the dominance of the population of B. carambolae, B. limbifera, Z. caudatus, and $B$. dorsalis. Based on the host range, some fruit flies are polyphagous, oligophagous, and monophagous. The host range of tephritid flies varies with species. Some are polyphagous, such as $B$. dorsalis, $B$. zonata, and Ceratitis capitata (Wiedemann), whereas others are oligophagous (Z. cucurbitae) or even monophagous (Bactrocera oleae, Rossi) (Biasazin et al. 2018). According to Plant Health Australia (2018), B. carambolae is polyphagous and has been reported to infest 75 hosts from 26 plant Families, including Anacardiaceae, Annonaceae, Clusiaceae, Lauraceae, Moraceae, Myrtaceae, Oxalidaceae, Rhamnaceae, Rutaceae, Sapotaceae, and Solanaceae. B. carambolae is known to be an essential pest on various fruit crops in Indonesia. Similarly, $B$. dorsalis is also polyphagous with a host range of more than 300 hosts and can oviposit in some fruit that has a hard pulp texture (Plant Health Australia 2018). Bactrocera limbifera is oligophagous with a limited host range in the Anacardiaceae Family (Dracontomelon dao) and Meliaceae Family (Aglaia sp.) (Drew and Romig 2013). Then, $Z$. caudatus is also oligophagous that is reported to have a host range in the flowers of Cucurbitaceae (Vargas et al. 2015).

Several fruit flies that do not have pest status, namely $B$. apicopicta, $Z$. borongensis, $D$. discophorus, and $D$. dorjii, are rare species with the low abundance that only exist in certain areas locations. Contrarily, species $B$. musae and $B$. pruniae are pests on banana (Musa sp.) and plum (Prunus sp.); however, limited host and the presence of other fruit fly species make the abundance of these two species low. B. musae is polyphagous and has as many as nine families of fruit plant hosts. However, it has only been reported in Australia, and its presence in Indonesia is still limited (Vargas et al. 2015). Bactrocera pruniae has never been reported before in Indonesia, this species is oligophagous that has a fruit host in the Rosaceae Family (Prunus persica) and has been reported to exist in North Vietnam (Vargas et al. 2015). The role of the host is considered quite important to the abundance of individual fruit flies. Fitrah et al. (2020) suggest that host availability significantly affects the fruit fly population. Most of the fruit flies found in both habitats were not pests. The status of fruit flies as pests or not is determined by the economic importance of their infestation in commercial commodities. Most fruit fly species infest non-commercial crops, such as tropical rainforest vegetation. The fruit flies are destructive pests, but the most damaged host plants are not the same in each country, depending on the fly species present. Most other species were reported from wild plants and do not have economic significance (Bouhalia and Kheder 2021). For example, in Australia, about 90 species of Dacinae have been described, but only a few of these are pests of introduced fruits (Dominiak and Worlsey 2018). Fruit flies are pests with essential meaning for agriculture; there are essential pests on fruits, including commercial fruits with high economic value. According to Vargas et al. (2015), the genus Bactrocera Macquart comprises 651 described species; thus, it is the most economically significant fruit fly genus with at least 50 species considered important pests, many of which are highly polyphagous. Almost all of the fruit flies recorded in an area confined to native tropical rainforest hosts have no potential as a pest and economic significance. Only a few species of the genus Bactrocera are considered pest status or be of market access importance worldwide (Royer and Hancock 2012).

Based on land use, habitat can affect the species composition of fruit flies. The individual abundance of each species that makes up the species composition differs between tropical rainforest and orchard habitats. Linda et al. (2018) stated that the study results indicated that the number of fruit fly species in the forest was more than that of fruit flies in the orchard or home estate. There was a difference in species composition in both habitats. The reason is that both habitats were considered capable of providing support for the survival of the various fruit fly species. Tropical rainforest habitats dominated by wild plants such as Samanea saman (Fabaceae), Tabernaemontana macrocarpa (Apocynaceae), Aglaia sp. (Meliaceae), Dalbergia latifolia (Fabaceae), Ficus sp. (Moraceae), and Dracontomelon dao (Anacardiaceae) have no association as hosts of most fruit fly species. However, the presence of tropical rainforest plants plays a role in providing canopy shade that protects fruit flies from direct sunlight. The canopy cover in tropical rainforests and orchards can directly affect the penetration level of sunlight into the ground surface, affecting the temperature and humidity required for insect life. According to Jihadi et al. (2021), the canopy cover in plantations by $66 \%$ to $78 \%$ makes high temperature and humidity. This high temperature affects the frequency and the activity of arthropods living in plantations. Another study shows that the canopy cover conditions affect the vegetation of plants and provide both floral and nectar resources in each land use; thus, the vegetation structures and species composition of plants positively affected arthropod species diversity (Wang et al. 2019). The types of vegetation in the orchard habitat are dominated by cultivated plants, including Cashew (Anacardium occidentale), Mangosteen (Garcinia mangostana), and Mango (Mangifera indica). The shade of grown trees can also protect against excessive sun exposure and create the ideal temperature and humidity for fruit flies. Rahinatou et al. (2020) suggested that the temperature and 
humidity play a role in fruit fly populations, when the temperature drops (below $30^{\circ}$ ) in increasing humidity (greater than $70 \%$ ), the population of $C$. cosyra decreases, whereas $B$. dorsalis increases. Meanwhile, according to Raghuvanshi et al. (2012), the temperature played a specific role in regulating the behavior of the fruit fly adults, which indicates the positive correlation of prevailing temperature with the number of ovipositing females; thus, the influence of relative humidity and rainfall harmed female abundance.

Vegetation in tropical rainforest and orchard habitats may be a potential source of nutrients and parapheromones that are important in the survival of adult fruit flies, thus affecting their species composition. Adult fruit flies are known not to consume fruit flesh like their larval stage but to obtain nutrients from various sources in nature. Adult fruit flies need a source of carbohydrates to survive. Shamshir and Wee (2019) suggested that the adult male fruit flies, in general, are non-damaging and often forage for sugary substances from floral nectar, overripe fruit sap, or on decaying organic matter. Meanwhile, according to Senior et al. (2016), several studies have suggested that fruit flies are attracted to plants that provide a source of food and shelter in the form of extra-floral nectaries, pollen, and bird feces, or honeydew produced by infestations of homopteran insects. The female fruit fly also needs protein for fecundity. Biasazin et al. (2018) suggested that the adult flies, particularly females, extensively forage for proteinaceous food sources. Adult Tephritid fruit fly females require protein sources for adequate egg production, and ammonia and its derivatives serve as volatile cues to locate protein-rich food (Pinero et al. 2017). The diversity of plants in the habitat is also considered capable of meeting the needs of parapheromone compounds that are important for the survival of fruit flies. These chemicals may play multiple roles in the mating system of fruit flies (Kumaran et al. 2014).

Natural habitats such as tropical rainforests can create more conducive environmental conditions for fruit flies, especially non-dominant species. This habitat has higher plant diversity than that of the orchard habitat. Therefore, competition between fruit fly species in the community structure is relatively low. Meyer et al. (2015) suggested that at least one abiotic factor (altitude) and two biotic ones (host availability, interspecific competition) are the primary screening factors for species dominance. Orchard habitats are artificial habitats that involve human intervention through plant cultivation activities. These habitats tend to be dominated by cultivated plants, so plant diversity is lower than tropical rainforest habitats. The existence of certain cultivated plants results in the potential for the development of certain species of fruit flies that have close associations with these cultivated plants. The species richness was influenced by the organic cultivation of the orchard and hosts in the forest (Monteiro 2019). Meanwhile, according to Vayssieres et al. (2009), the existence of plants deliberately cultivated in high numbers dramatically affects the population of fruit fly species that become pests of these plants. In addition, the period that had the lowest population peaks was precisely in the months when the native vegetation of the region suffered from adverse climatic factors and consequently produced fewer fruits, which would serve as hosts for the flies (Madalon et al. 2017).

The conclusion that can be drawn is that the diversities of fruit flies in tropical rainforest and orchard habitats differ significantly in abundance but not in species richness. In addition, the species composition differs between tropical rainforest and orchard habitats. It indicates that habitat type has an essential role in shaping fruit fly communities in Lombok Island.

\section{ACKNOWLEDGMENTS}

The author would like to thank the Agricultural Extension and Human Resources Development Agency, the Ministry of Agriculture, the Republic of Indonesia for the scholarship given to the study assignment program in 2018 and the Agricultural Quarantine Agency Class 1 Mataram for facilitating the laboratory.

\section{REFERENCES}

Aryuwandari VEF, Trisyono YA, Suputa, Faveri S, Vijaysegaran S. 2020. Survey of fruit flies (Diptera: Tephritidae) from 23 species of fruits collected in Sleman, Yogyakarta. J Perlindungan Tanaman Indones 24: 122-132. DOI: 10.22146/jpti.57634

Badan Pusat Statistik NTB. 2020. Dynamic table. https://ntb.bps.go.id/site/resultTab. Accessed March 10, 2021.

Biasazin TD, Chernet HT, Herrera SL, Bengtsson M, Karlsson MF, Lemmen JK, Dekker T. 2018. Detection of volatile constituents from food lures by Tephritid fruit flies. Insects 9: 1-14. DOI:10.3390/insects9030119

Bouhalia S, Kheder. 2021. Review on major fruit flies (Diptera: Tephritidae) in North Africa: Bio-ecological traits and future trends. J Crop Prot 140: 105416. DOI: 10.1016/j.cropro.2020.105416

CABI (Centre for Agriculture and Bioscience International). 2019. Bactrocera dorsalis (Oriental fruit fly) [original text by Luc Leblanc]. In Invasive Species Compendium. CAB International, Wallingford, UK. www.cabi.org

Dominiak BC, Worlsey P. 2018. Review of cucumber fruit fly, Bactrocera cucumis (French) (Diptera: Tephritidae: Dacinae) in Australia: Part 1, host range, surveillance and distribution. J Crop Prot 106: 79-85. DOI: 10.1016/j.cropro.2017.11.015

Doorenweerd C, Ekayanti A, Rubinoff D. 2020. The dacini fruit fly fauna of Sulawesi fits Lydekker's line but also supports Wallacea as a biogeographic region (Diptera, Tephritidae). ZooKeys 973: 103-122. DOI: 10.3897/zookeys.973.55327

Drew RAI, Romig MC. 2013. Tropical fruit flies (Tephritidae: Dacinae) of South-East Asia lndomalaya to North-West Australasia. CABI Wallingford, Oxfordshire, Cambridge, MA. DOI: 10.1079/9781780640358.0000

Fahrig L, Baudry J, Brotons L, Burel FG, Crist TO, Fuller RJ, Sirami C, Siriwardewa GM, Martin JL. 2011. Functional landscape heterogeneity and animal biodiversity in agricultural landscapes. Ecol Lett 14: 101-112. DOI: 10.1111/j.1461-0248.2010.01559.x

Fitrah R, Pranowo D, Suputa. 2020. Oviposition preference of Bactrocera dorsalis Hendel (Diptera: Tephritidae) on different fruit in snake fruit orchard. J Perlindungan Tanaman Indones 24: 224-228. DOI: 10.22146/jpti.52825

Foster WA, Snaddon JL, Turner EC, Fayle TM, Cockerill TD, Ellwood MDF, Broad GR, Ching AYC, Eggleton P, Khen CV, Yusah KM. 2011. Establishing the evidence base for maintaining biodiversity and ecosystem function in the oil palm landscapes of South East Asia. Phil Trans R Soc B 366: 3277-3291. DOI:10.1098/rstb.2011.0041

Grimbacher PS, Nichols C, Wardhaugh CW, Stork NE. 2014. Low host specificity of beetles associated with fruit falls in lowland tropical 
rainforest of north-east Australia. Austral Entomol 53: 75-82. DOI 10.1111/aen.12049

Grove T, de Jager K, Theledi ML. 2019. Fruit flies (Diptera: Tephritidae) and Thaumatotibia leucotreta (Meyrick) (Lepidoptera: Tortricidae) associated with fruit of the family Myrtaceae Juss. in South Africa. J Crop Prot 116: 24-32. DOI:10.1016/j.cropro.2018.10.008

Jihadi A, Rizali A, Atmowidi T, Pudjianto, Buchori D. 2021. Diversity and species composition of bees in different land-use types in Jambi, Indonesia. J Int Soc Southeast Asian Agric Sci 27: 38-46

Kumaran N, Hayes RA, Clarke AR. 2014. Cuelure but not zingerone make the sex pheromone of male Bactrocera tryoni (Diptera: Tephritidae) more attractive to females. J Insect Physiol 68: 36-43. DOI: 10.1016/j.jinsphys.2014.06.015

Linda, Witjaksono, Suputa. 2018. Species composition of fruit flies (Diptera: Tephritidae) in Sorong and Raja Ampat, West Papua. J Perlindungan Tanaman Indones 22: 193-200. DOI: 10.22146/jpti.25280

Madalon FZ, Prezotti L, Meneghelli CM, Carvalho JR, Pirovani VD, Madalon RZ, Maciel KS, Lauvers GS, Correa JM, Mellere JGB. 2017. Populational dynamics of fruit flies (Diptera: Tephritidae) in guava orchards in the Northwest region of Espírito Santo, Brazil. Afr J Agric Res 12: 2851-2857. DOI: 10.5897/AJAR2017.12523

Meyer M, Delatte H, Mwatawala M, Quilici S. 2015. A review of the current knowledge on Zeugodacus cucurbitae (Coquillett) (Diptera, Tephritidae) in Africa, with a list of species included in Zeugodacus. ZooKeys 540: 539-557. DOI: 10.3897/zookeys.540.9672

Mokam DG, Chantal AD, Pierre LJ, Gerard D, Champlain DL. 2014. First record of Dacus (Lophodacus) hamatus (Diptera: Tephritidae) in Cameroon, with emphasis on a new host plant Lagenaria siceraria (Cucurbitaceae). Afr J Agric Res 9: 636-642. DOI:10.5897/AJAR2013.7600

Monteiro LB, Tomba JAS, Nishimura G, Monteiro RS, Foelkel E, Lavigne C. 2019. Faunistic analyses of fruit fly species (Diptera: Tephritidae) in orchards surrounded by Atlantic Forest fragments in the metropolitan region of Curitiba, Parrana state, Brazil. Braz J Biol Sci 79: 395-403. DOI:10.1590/1519-6984.178458

Pinero JC, Souder SK, Smith TR, Fox AJ, Vargas RI. 2017. Attraction of Bactrocera cucurbitae and Bactrocera dorsalis (Diptera: Tephritidae) to beer waste and other protein sources laced with ammonium acetate. Fla Entomol 100: 70-76. DOI: 10.1653/024.100.0112

Plant Health Australia. 2018. The Australian Handbook for the Identification of Fruit Flies. Version 3.1. Plant Health Australia. Canberra, ACT. DOI: 10.21926/obm.geriatr.1902056

Raghuvanshi AK, Satpathy S, Mishra DS. 2012. Role of abiotic factors on seasonal abundance and infestation of fruit fly, Bactrocera cucurbitae (coq.) on bitter gourd. J Plant Prot Res 52: 264-267. DOI: 10.2478/v10045-012-0042-3

Rahinatou RA, Bassirou D, Amadou C, Youssouf F K, Bernard S. 2020. Infestation rate of Mangifera indica fruit fly in Sudanese zone of Mali. J Entomol Nematol 12: 10-17. DOI:10.5897/JEN2019.0240

Reilly SB, Stubbs A, Karin B, Bi K, Arida E, Iskandar D, McGuire J. 2019. Leap-frog dispersal and mitochondrial introgression: Phylogenomics and biogeography of Limnonectes fanged frogs in the Lesser Sundas Archipelago of Wallacea. J Biogeogr 46: 757-769. DOI: $10.1111 /$ jbi.13526
Royer JE, Hancock DL. 2012. New distribution and lure records of Dacinae (Diptera: Tephritidae) from Queensland, Australia, and description of a new species of Dacus Fabricius. Aust J Entomol 51: 239-247. DOI:10.1111/j.1440-6055.2012.00864.x.

Royer JE, Mayer DG. 2018. Combining cue-lure and methyl eugenol in traps significantly decreases catches of most Bactrocera, Zeugodacus and Dacus Species (Diptera: Tephritidae: Dacinae) in Australia and Papua New Guinea. J Econ Entomol 111: 298-303. DOI: 10.1093/jee/tox334

Royer JE, Teakle GE, Ahoafi E, Mayer DG. 2019. Methyl-isoeugenol, a significantly more attractive male lure for the methyl eugenolresponsive Pacific fruit fly, Bactrocera xanthodes (Diptera: Tephritidae). Austral Entomol 58: 800-804. DOI: 10.1111/aen.12398.

Sapta S, Sulistyantara B, Fatimah IS, Faqih A. 2015. Geospatial approach for ecosystem change study of Lombok Island under the influence of climate change. The 1st International Symposium on LAPAN-IPB Satellite (LISAT) for Food Security and Environmental Monitoring 24: 165-173. DOI:10.1016/j.proenv.2015.03.022

Senior LJ, Wright CL, Missenden B, DeFaveri S. 2016. Protein feeding of Queensland fruit fly Bactrocera tryoni and cucumber fly Zeugodacus cucumis (Diptera: Tephritidae) on non-host vegetation: Effect of plant species and bait height. Austral Entomol 56: 296-301. DOI: 10.1111/aen.12231

Shamshir RA, Wee SL. 2019. Zingerone improves mating performance of Zeugodacus tau (Diptera: Tephritidae) through enhancement of male courtship activity and sexual signaling. J Insect Physiol 119: 103949. DOI: $10.1016 /$ j.jinsphys.2019.103949

Suntono, Kadek AM, Baiq K, Ike R, Meta I. 2019. Statistics of horticultural crop production in West Nusa Tenggara Province 2018. Badan Pusat Statistik Provinsi Nusa Tenggara Barat, Mataram. [Indonesian]

Supratiwi R, Apriyadi R, Asriani E. 2020. Fruit flies (Diptera: Tephritidae) diversity in horticultural farm of Merawang sub-district, Bangka District, Bangka Belitung Islands. JHPT Tropika 20: 61-70. DOI : $10.23960 /$ j.hptt.12061-70

Tan KH, Nishida R. 2013. Pollination of Bactrocerophilous Bulbophyllum Orchids. Proceedings of the 20th World Orchid Conference: Where new and old orchids meet. Singapore Botanic Gardens.

Vargas RI, Pinero JC, Leblanc L. 2015. An overview of pest species of Bactrocera fruit flies (Diptera: Tephritidae) and the integration of biopesticides with other biological approaches for their management with a focus on the pacific region. Insects 6: 297-318. DOI:10.3390/insects6020297

Vayssieres JF, Korie S, Ayegnon D. 2009. Correlation of fruit fly (Diptera: Tephritidae) infestation of major mango cultivars in Borgou (Benin) with abiotic and biotic factors and assessment of damage. J Crop Prot 28: 477-488. DOI: 10.1016/j.cropro.2009.01.010

Wang X, Hua F, Wang L, Wilcove DS, Yu DW. 2019. The biodiversity benefit of native forests and mixed-species plantations over monoculture plantations. Divers Distrib 25: 1721-1735. DOI: 10.1111/ddi.12972

Zubair U, Shehzad A, Mastoi MI, Mahmood K. 2019. New record of fruit flies (Diptera: Tephritidae) from Poonch Division of Azad Jammu and Kashmir. Pak J Agric Sci 32: 466-473. DOI: 10.17582/journal.pjar/2019/32.3.466.473. 